\section{Violence in Venezuela: oil rent and political crisis}

\author{
Violência na Venezuela: \\ renda petroleira e crise política
}

${ }^{1}$ Laboratario de Ciencias Sociales (Lacso).

Av. A. Codazzi, Quinta

Lacso, Santa Monica, 1041

Caracas, Venezuela.

bricenoleon@cantv.net
Abstract This article analyzes the changes in violence in Venezuela during the last forty years. It links the ups and downs of the oil revenues and the political crisis of the country to the changes in the homicide rates, which increased from 7 per 100 thousand inhabitants in 1970 to 12 in 1990, 19 in 1998 and 50 in 2003. The article characterizes Venezuela as a rentist society and shows its trajectory from rural violence to the beginning of urban violence, the guerilla movements of the 60 s, the delinquent violence related to the abundance of oil revenues and the violence during the popular revolt and the sackings of 1989 in Caracas. After this, we analyze the coups d'état of 1992 and the influence the political violence exerted upon criminal violence. We describe the political and party changes in the country, their influence upon the stabilization of homicide rates since the mid-90s and their remarkable increase during the $H$. Chávez government. The article finishes with an analysis of the current situation, the official prohibition to publish statistics on homicides and with some thoughts about the perspective of greater violence in Venezuela.

Key words Violence, Venezuela, Public health, Homicides, Oil, Politics
Resumo O presente artigo analisa as mudanças na violência ocorridas na Venezuela nos últimos quarenta anos, relacionadas com os altos e baixos da renda petroleira e com a crise política no país, fatos que contribuíram para um aumento nas taxas de homicídios: de 7 por cada cem mil habi-

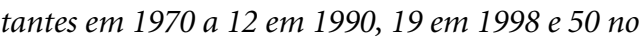
ano de 2003. O artigo caracteriza a Venezuela como sociedade rentista e, a partir daí, faz uma retrospecção cobrindo desde a violência rural até os inícios da violência urbana, o movimento guerritheiro dos anos sessenta, a criminalidade resultando da abundância dos recursos petroleiros e a violência em decorrência da revolta popular e dos saques ocorridos em 1989 em Caracas. Em seguida são analisados os golpes de Estado de 1992 e o impacto que a violência politica exerceu sobre a violência criminal. Descrevemos as mudanças políticas e partidárias no país e sua influência sobre a estabilização das taxas de homicídios em meados dos anos noventa, assim como, seu considerável aumento durante o governo Chávez. O artigo conclui com uma análise da situação atual, fala sobre a proibição de publicar dados estatísticos sobre homicídios e faz uma reflexão sobre a perspectiva de ainda mais violência na Venezuela. Palavras-chave Violência, Venezuela, Saúde pública, Homicídios, Petróleo, Política 


\section{Introduction}

Violence did not represent an important problem for public health in Venezuela until the end of the 20th century. During several decades and since reliable statistics were available, the homicide rates oscillated between six and ten deaths per 100 thousand inhabitants. Although they were high in comparison to those of Argentina and Costa Rica, they were extremely low in comparison to those of the neighbor Colombia. For decades Venezuela was not a country that produced news, neither did it call the attention of researchers, sponsors or European research centers: there was no remarkable poverty, no important indigenous population, no guerilla or violence. It was this way, because after the bloody independence war and the civil wars of the 19th century, the country entered a process of economic growth, political stability and improvement of the social and health systems, made possible by the dominating role the increasing income of the petroleum industry played in the economyl, 2,3,4. The distribution of this income from the petroleum industry caused a remarkable transformation of the country and resulted in an institutional construction process that turned the Venezuelan public health into an example for many countries in the region 5 .

The situation in the beginning of the new century is very different. With a homicide rate in turn of 50 deaths per 100 thousand inhabitants, Venezuela is among the most violent countries in the region, a not very honorable place it is sharing with traditionally violent countries with recent internal wars like Colombia and El Salvador.

The greater part of the 20th century was a period of increasing social movement and improvement of the health conditions of the population. During this period, the great epidemics were under control and the poorer populations in the country and in the cities had access to health care and labor opportunities. This was also the period in which the modern institutions appeared and the State of Law got fortified 6 . In the end of the century, the situation was different.

Since the 80s, the Venezuelan society initiated a process of changes and crises that has still not come to an end. The society became poorer, more instable and more violent. In the course of two decades, the homicide rate multiplied by ten while the population did not even grow to the double. The number of homicides that were committed in the country in the beginning of the 80 s did not reach the number of 1,300 deaths per year; twenty years later it surpasses the number of 13,000 assassinations.

Violence became one of the most important public health problems in Venezuela and this is the result of the crisis of the oil export society model, which during sixty years had changed the face o the country7 ${ }^{7}$ A model, which during decades had been able to create and sustain the extraordinary condition of concomitantly ensuring better wages for the workers and growing profits for the entrepreneurs. This was possible due to the singular position the State and democracy occupy in the oil export society ${ }^{8}$. The Venezuelan economy is dominated by the petroleum sector, which accounts for a third of its gross domestic product (36\% in 2005) and for more than $80 \%$ of export revenue, but which employs only $2 \%$ of the total labor force.

The earnings from the petroleum sector go to the hands of the central government, which uses them according to its judgment. In this society, the State, sustained by the oil export earnings, is completely independent from the economical point of view, a State that does not need society for its economical survival, it only needs the oil companies and the global market ${ }^{9}$. It is a rentist State and a rentist society. We call the earnings resulting from the oil export a rent for two of its characteristics. On one hand, it is not really a rent because it lacks the trait of perenniality claimed by D. Ricardo ${ }^{10}$, and the sale of a not renewable natural resource rather represents the liquidation of an asset, but society perceives it as a rent for being almost one hundred years present in the country. On the other hand, it has the characteristic of the surplus profit Karl Mark attributed to the term "rent", when giving the example of wine of very extraordinary quality11. This is why the income of the society could vary so greatly from one year to the next as, when it tripled between 1973 and 1974 or quintupled between 1998 and 2005 , although nothing special had been done by the Venezuelan society (workers and the industry) to increase productivity, because the price of the product does not depend on production processes or costs but rather on other variables, many of them as political as a threat of a war in the Middle East.

The crisis of this model, to the same extent artificial and successful, shows the transformations experienced by the society and forms part 
of the recent history of public health in Venezuela.

\section{From rural to urban violence}

Between 1926 and 1979, the people in Venezuela lived a period of great social inclusion. During this period, the Venezuelans lived increasingly better, during several decades the workers were able to obtain gains which, in concrete terms, increased from year to year ${ }^{12}$. The wages paid in Venezuela were during decades higher than those paid in Europe ${ }^{13}$.

This modernization process also transformed the conflictivity; the traditional rural violence decreased and other forms arose, like the armed guerilla fights and the violence related to wealth. The change of territories transformed Venezuela in less than one hundred years from a rural country, where about $90 \%$ of the population was living in the country, into a clearly urban country, where more than $80 \%$ of the population lives in the cities. This spatial change also implied in a great social change. The families could live in better houses and had better access to public services. Their children were born with medical assistance and frequented public schools. The country lived an important institutionalization process allowing a strengthening of political and civil citizenship 14 .

With these changes, rural violence decreased radically. On one hand, the individuals feeling at risk migrated to the cities and, on the other hand, the institutionalization, the State of Law and its agents (malaria inspectors, police and army) reached the most distant margins of the territory. The country was unified and found itself in the migrations and in the strengthening of the State. The dictator J. V. Gómez, who ruled the country during the first thirty years of the 20th century, had promised to put an end to the revolts and struggles between caudillos and large landowners, only to turn himself into the greatest landowner and the only caudillo of the nation.

Venezuela, with its accelerated urbanization between the 40 s and 60 s of the 20th century, was at the same time constructing a society without violence. It was a country believing in the State of Law as the adequate response to the needs of social life and for the solution of the conflicts of the modernizing society.

This process was interrupted in the beginning of the 60s, with the appearance of a rural guerilla movement with very few urban expressions. Venezuelan democracy was born in the end of the 50s (1958) nearly at the time of the triumph of the Cuban revolution (1959). In 1957, the military forged a referendum with the intent to perpetuate their power but a few months later, in January 1958, a general strike forced them to withdraw from the country. The fight against the military dictatorship of $\mathrm{M}$. Pérez Jiménez was never marked by violence, it was a political and labor union movement and although it suffered repression by the government, tortures and murders, it did not trigger armed confrontations. However, some groups of young people that had participated in the underground resistance against the dictatorial regime saw in the focused guerilla warfare, as it had been used in Cuba, the model to be followed in their ambition to take over the power. The political orientation of this movement was not clear, it was not a communist movement, but these changes must be understood in the context of the cold war and of the process by which Cuba becomes communist and decides to impel the Latin American guerilla movement with the intent to create "one, two, three Vietnams". A fraction of the Venezuelan socialdemocratic party that made part of the government (Accion Democratica) took leaders of the young party members to guerilla activities; concomitantly, a change in the strategy of the Venezuelan communist party leads to the sprouting of different guerilla fronts, receiving support and training from the Cuban government. Their breath however was very short. Their political project did not convince the Venezuelan population. People were interested in improving their quality of life and in ascending socially; therefore the reformist policies of the government, financed with the oil revenue, were able to isolate these groups, to deprive them from their social support basis. There were no more landowners and civil leaders to instigate the hatred of farmers, as was the case in Colombia, and the few who continued struggling after the first impact of the petroleum were eliminated with the agrarian reform or lost their power with the new rural emigration that took place at that time.

The guerilla was fought by the Venezuelan army, but we do not believe that their defeat was basically due to the military actions, but to the social reforms that took place. The agrarian reform, the devolution of the land, the agricultural loans, the primary and graduate schools, 
the environmental sanitation programs in the rural communities, the rural habitation program, in short, the oil income spent in social programs, allowed farmers to achieve a better life with their work and governmental support, not guerilla warfare.

After the armed groups failed in their attempt to sabotage the presidential elections in 1963, and the government for the first time was passed pacifically from one elected president to another, it became very clear for the country that the political violence had been defeated. The pacification process that took place in the following years and governments allowed a safe incorporation of the former guerrillas into the democratic political life. Their pacification can be considered successful because they came to form parties and participated in elections without being subject to open political repression or concealed revenge like it occurred in Colombia. The incorporation of important guerrilla leaders to legal and democratic political activity changed the Venezuelan left and allowed the consolidation of a policy of peace in the country.

The immense oil revenue that flew into the country after the oil crisis of 1973, in only one year tripling the income of the central government, allowed sustaining the pacification policy. Who would be interested in supporting the guerrilla while there was so much money in "Saudi Venezuela"? The problems that appeared from this moment on were of another type. After 1975, the country witnessed the appearance of a type of violence related to crimes against the property, assaults to families, stores and banks. This violence did not arise from poverty but from abundance. Venezuela suddenly became the focus of interest of a great number of domestic or imported delinquents: there was too much money. A minor bank robber we had the opportunity to interview at that time, gave an impeccable explanation: Instead of risking my life in Barranquilla for 100 thousand Colombian pesos, he said to us, I prefer to do it in Venezuela for 100 thousand Venezuelan bolivars, an amount that, at the dollar exchange rate of the moment, represented much more money. The risk was the same but the benefit was much higher.

Nevertheless, this kind of delinquency was not particularly lethal. It had increased the crime rates but not mortality, because the homicide rates had not increased significantly. Perhaps these crimes were very eye-catching and people were surprised by the involved amounts of money, but in a study we carried out in the interior of the country we observed that people imagined the risk to be much greater than it really was, according to the police records ${ }^{15}$. Anyway, still in the mid-eighties, when a group of catholic universities directed by the Jesuits decided to perform a multinational study on violence, the international committee was very much in doubt if Venezuela was an appropriate subject for this study, because it did not seem to them that violence was an important problem in the country. A little after, it turned out that it was 16 .

\section{The broken dreams: 1983}

From 1983 on, the country changed for the Venezuelans. For nearly 20 years, Venezuela had a freely convertible currency and a fixed exchange rate (one dollar/4.3 bolivars). This fixed exchange rate meant a continuous readjustment of the national currency, because internally the currency lost value due to inflation that, although small, existed every year. Externally however, the currency conserved its value, with the result that imported products were, from year to year, becoming less expensive than the domestic ones. In February 1983 the situation became unsustainable and on the day the country baptized the "black Friday" the currency was devaluated and a strict control of import revenues was implemented. The crisis that expressed itself in this moment represented much more than a measure for controlling imports, it revealed to the citizens the fragilities of this model of society and of the dreams of a sustainable development they had nourished 17 .

The real wages of the Venezuelans, which had been continuously rising since the 50 s, freeze at the beginning of the 80 s and from then they begin a never-ending decline. For some authors the crisis was originated in 1977 when, after the oil nationalization, foreign private investment stopped in the country ${ }^{18}$. However, people only began to feel this in their bones and in their pockets several years later.

The Mexican crisis of August 1982 was not understood as the foreshadow of a conflict, like an omen, but like something external, belonging to that country, something that could not happen in Venezuela. The crisis that became visible in 1983 was accompanied by a period of economic retrocession all over Latin America; 
years of stagnation that many analysts are inclined to call the "lost decade".

In 1983, Venezuela registered a rate of eleven homicides per 100,000 inhabitants. As it can be observed in graph 1, this number declined slightly in the following years and dropped to around ten homicides in 1984 and 1985, and soon to eight homicides in 1986 and 1987. These homicide rates were very similar to those shown by the United States of America, although they were not as low as the rates shown by Costa Rica or Argentina, they were in fact very inferior to those of Colombia or El Salvador.

We understand these years as an incubation period of violence because, although during this space of time the process of social inclusion and constant ascension of the population had ceased 19 , it was not characterized by social crisis or violence. People still had their savings and hoped that the problems were transitory and that soon everything would return to the times of plentifulness of the end-seventies.

Maybe this is the reason why the violence rates do not increase in Venezuela as early as in other Latin American countries, where they rise no matter if these countries had passed through a period of intense violence - like Colombia - or of little violence - like Brazil.
For Venezuela this is the period of social surprise, something new was going on but people did not know very well how to interpret it. Some understood that a greater crisis was about to happen and therefore not only the migratory pressure towards Venezuela ceases, but many immigrants - the old ones from Europe as well as the new ones from the Southern Cone - and their capital started to leave the country. Others preferred keeping the hope of this being only a difficult moment that would pass and not the deep crisis that was announcing itself 20 . However, for 1988, the country maintained the social peace with a homicide rate of only one digit: 9 homicides per one 100 thousand inhabitants.

\section{Social violence: 1989}

The electoral campaign of 1988 was a fictitious discussion trying to revive the years of wealth. The government employed all efforts for carrying on the same distributive and State model, but without availing of the financial resources that had made this possible. The government of J. Lusinchi (1984-1989) followed a policy of artificial price control that encouraged corruption, monopolization and caused a remarkable

\section{Graph 1}

Venezuela 1983-2003. Homicide rate per 100,000 inhabitants.

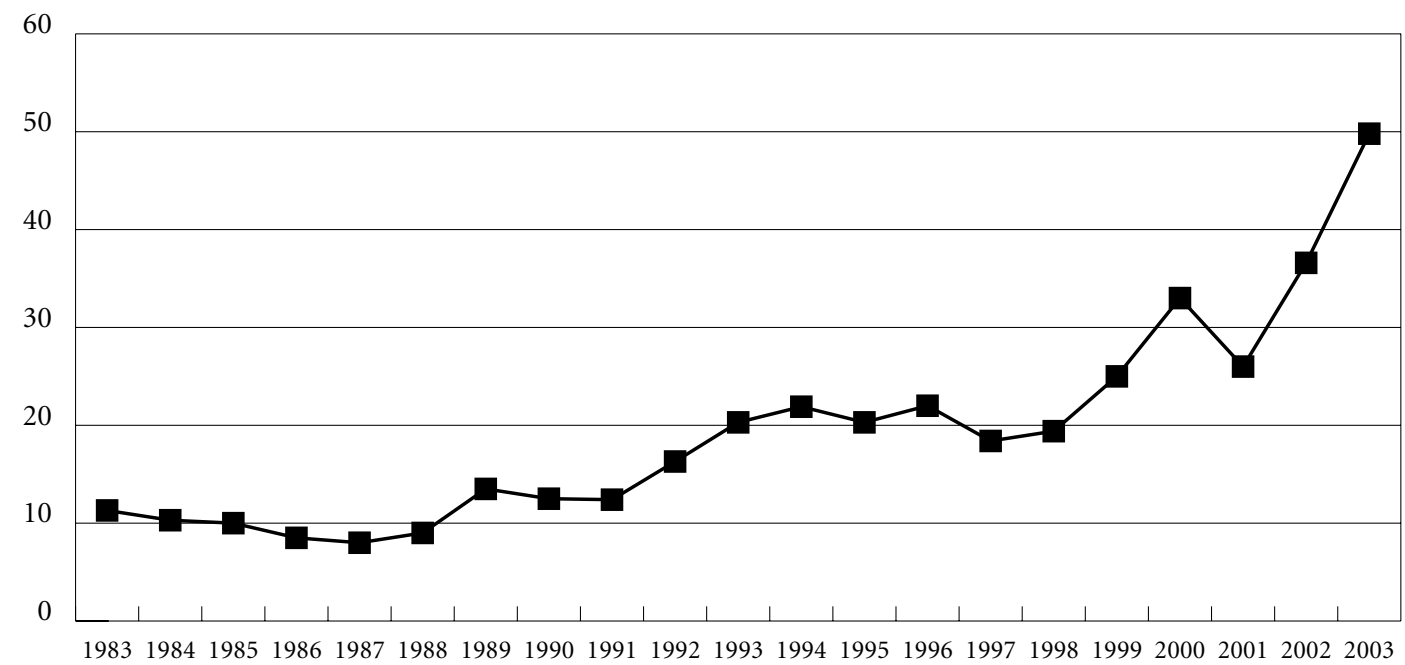


shortage of products as basic as milk, sugar or feminine sanitary towels. The reelection of Carlos Andrés Perez (1988) represented a very impressive invocation of happy memories of times of wealth used as a tactic to win the elections. But the president demonstrated very soon, and already in the government, that he was determined to break with the past: the power of the parties of the bureaucratic apparatus and the rentist economy of the oil industry.

The beginning of his administration, however, was full of conflicts. The discontent of society caused by the permanent shortage of products, as well as the contrast between the image the voters had of their populist and distributive candidate and the first economic measures taken by the government, caused the most important social revolt of the century. Many people felt that the wealth had gone or that it was in the hands of only a few and that therefore they had to take possession of the little that was left.

The sackings of February 27 and 28, 1989, were violent, not only in their expression doors of shops broke down by force and people sacking whatever was in reach - but also in the repressive answer on the part of the security authorities and the armed forces.

The number of deaths during the days of this revolt was calculated in several thousand. A study carried out based on data of the morgue of Caracas revealed 534 deaths during those days 21 . Our results were much lower than the speculations made by the press, but, nevertheless, they were very high. There is always the possibility of some deaths not having been registered, but in comparison to a homicide rate in the previous years around 1,500 all over the country during a full year, a number of five hundred deaths only in Caracas in the course of one week is extremely high.

The deaths occurred in the most different ways. There were people who were killed by shop owners trying to defend their property; there were homicides between plunderers, professional criminals disputing some valuable loot; common people that simply fell down the stairs trying to escape and died from multiple traumatisms; people died in the confrontations with the army; and there were also fatalities, like the one of the lady, who was quietly observing a confrontation from the balcony of her apartment in the 13th floor of a building, when she suddenly fell dead next to her adolescent daughter, hit by a lost bullet.
The homicide rate in 1989 increases 4.5 points, reaching 13.5 deaths per 100 thousand inhabitants; this was an increase of $50 \%$ in relation to the previous year. As can be seen in graph 1 , the homicide rate decreased slightly in the following years, 1990 and 1991, to 12.5 and 12.4 respectively, but it did not return to the level of 1988.

So one asks: what was it that stopped that strange orgy, that sudden rupture of the social pact these sackings represented? One might think that it were the repressive actions of the army, however I have the impression that it was the people themselves, who put an end to it. Even the people in the poor neighborhoods of the city were intimidated by the disorder, and the families with low income were scared of becoming victims of plundering as well. It was a real fear but, at the same time, it was also a symbolic fear, the fear from madness, because plundering out of control is a kind of madness. Thus, these fears are expressing a rupture of the social pact and of the symbolic order.

\section{The coups d'état: 1992}

Another important rupture of the pact is represented by the attempts of a coup d'état in 1992. In this case, we are talking about the rupture of the political pact and the symbolic order democracy represents, also with important violent consequences.

Paradoxically, the same President of the Republic who, in the 70s, had conducted the exacerbation of the rentist oil model, C.A. Pérez (1974-1979), presented fifteen years later the only important proposal for its transformation by the government (1989-1993). It was a rupture with rentism and a possibility of constructing a non-oil, non-distributionist and non-statist society. The proposal could and can be criticized from a series of viewpoints, but to the present time, Chávez and his revolutionary boasts notwithstanding, it was the only time the government proposed a true change of the economy and the Venezuelan society. That proposal, however, was defeated by the rentist and caudillist mentality that prevailed in the country.

The coups d'état of February and November 1992 showed the ugly face of political violence and generated an institutional crisis that should increase criminal violence far beyond the violence that had occurred during the year and the days of the attacks. The attempts of the 
coups d'état caused violent deaths among the military who participated in the confrontations and among the civil population, but the homicides did not finish there because the crisis of legitimacy that the coups d'état originated was too great, and once broken the symbolic pact criminals as well as common people felt more at ease with using violence.

In 1992, the rate of homicides reached the number of 16.3 deaths per 100 thousand inhabitants, 4 points more than in the previous year. In 1990 and 1991, 2,474 and 2,502 homicides were registered in the country respectively, shall say, an almost identical number. In 1992 however, the rate jumps to 3,366, shall say, 866 more cases of homicides, representing an increase of $34 \%$ between one year and the other. But, as we can see in table 1 , the impact the coups d'état exerted on violence went still beyond. Violence did not stop when the military rebels were defeated and put in jail but continued to increase in the following years, seeing that, in 1993, 4,292 homicides were registered, a rate of 20.3 homicides per 10,000 inhabitants. Shall say, the rate increased 4 points again, and increases again in 1994 when 4,733 murders were committed, reaching a level of 22 homicides/100,000 inhabitants.

In summary, one can say that between the coups d'état of 1992 and the beginning of the government of R. Caldera (1994-1999), the incidence of homicides almost duplicated in absolute numbers in the country. Taking into account the population growth, we can say that the homicide rate passed from 12 to 22 victims per 100 thousand inhabitants. This could not be a coincidence. The political crisis of those years and the rupture of the social pact of democracy, expressed by the armed attempts to change the government, had very serious consequences for day-to-day violence. In only a couple of years, one President of the Republic was deposed and two presidents and two provisional governments were instituted, in a climate of uncertainty and under the threat of a new coup d'état.

During this period the limit of 4,000 homicides per year in the country was surpassed and the alarm lights lit because of a new social phenomenon coming up in Venezuela. Violence turned into a problem that was no longer punctual, it was no longer a moment or a day of rage and revolt, but affected the daily life of the people regularly22. This was the moment, when the Pan American Health Organization decided to

\begin{tabular}{lccc}
\hline $\begin{array}{l}\text { Table } 1 \\
\text { Homicides in Venezuela }\end{array}$ & 1990-2003. \\
\hline & $\begin{array}{c}\text { Total of } \\
\text { Homicides }\end{array}$ & $\begin{array}{c}\text { Population } \\
\text { (in millions) }\end{array}$ & $\begin{array}{c}\text { Rate per 100,000 } \\
\text { inhabitants }\end{array}$ \\
\hline 1990 & 2,474 & 19.7 & 12.53 \\
1991 & 2,502 & 20.1 & 12.38 \\
1992 & 3,366 & 20.6 & 16.29 \\
1993 & 4,292 & 21.1 & 20.32 \\
1994 & 4,733 & 21.5 & 21.92 \\
1995 & 4,481 & 22.0 & 20.32 \\
1996 & 4,961 & 22.9 & 22.04 \\
1997 & 4,225 & 23.4 & 18.40 \\
1998 & 4,550 & 23.4 & 19.43 \\
1999 & 5,974 & 23.8 & 25.02 \\
2000 & 8,021 & 24.3 & 32.99 \\
2001 & 6,432 & 24.7 & 25.97 \\
2002 & 9,244 & 25.2 & 36.65 \\
2003 & 13,288 & 26.0 & 50.96 \\
2004 & Publication of & & \\
& data forbidden & & \\
\hline
\end{tabular}

Source: LACSO. Data assembled from the Organism of Scientific Penal and Criminal Investigations and the National Institute for Statistics.

include Venezuela in the multicentric study being developed for establishing norms and attitudes towards violence. During these years, the natives of Caracas began to be frightened even by the noise of an innocent firework, thinking it could be a new military rise.

Since 1995, a transitory stability took place in the country. The elections of 1994 showed that the democratic pact was still effective and that a pacific change of the government by means of elections was possible, but the political parties were in a very deep crisis 23 . The course chosen by the country in these elections was very strange. People decided to vote for a political change in a very twisted manner, seeing that for defeating the young candidates of the two parties that had shared the power for 40 years, they chose a candidate of older age and best representative of the traditional policy of the country: R. Caldera. Shall say, the candidate who, from an objective viewpoint, more than any other represented the past, was adopted by the population like a messenger of the times to come. The population wanted to vote against the parties, and for this they took advantage of the best living representative of the traditional parties and founder of one of them.

The government of Caldera (1994-1999) brought no important political or social change, but it restituted stability to the country. The so- 
cial pact was recovered and this was translated in a stabilization of social relations and political conflictivity. Returning to graph 1 , one can observe that the death rate stabilizes, it oscillates around 20 homicides throughout the period, and that the total number of murders declined in nearly every year of the period (with exception to 1996). When considering the normal population growth, we find even a slight reduction in the homicide rates in 1997 and 1998. The country had overcome the traumas of the coups d'état and of the bank crisis, but the damage to the legitimacy of democracy and social division was already done.

\section{The beautiful revolution: 1999}

It seemed that the country had been looking for a savior caudillo since the 80s. Perhaps, in the deep of their heart, people were looking for a figure able to restitute the advantages of the oil model because they could not accept - and this is true for all sectors of society - its unfeasibility and failure, or did they dare to face the challenges and fears of the novel. What else could explain this electoral choice? The second governments of C.A. Perez (1989-1993) and R. Caldera (1994-1999) were an illusionary attempt to substitute the evils of the present by nostalgia for the good old times, as if it were the will of the leaders and not the hard realities of politics and economy that determine the good and the bad moments on the way. The leaders, of course, can always make things worse.

From 1999 on, a still ongoing political crisis began in Venezuela. During this period homicides have increased to an extent that no analyst could have imagined. While lieutenant colonel Chávez was engaged in his electoral campaign in 1998, 4,550 homicides were committed all over the country. Six years after his government, there were 13,288 homicides, almost three times more. The homicide rate that in 1998 was of $19.5 / 100$ thousand inhabitants, rose to 51 homicides/100 thousand inhabitants in 2003, shall say, an increase of twenty points without a formal declaration of war. This is an abysmal increase and a behavior of the curve impossible to be characterized technically as a normal tendency. What happened in these years?

On one hand, the political crisis unleashed violence and, on the other hand, the government hindered its control and repression, and has done this in every possible way. Be it inten- tionally or not, be it as a political strategy or be it an undesired consequence, the results we have seen.

The Chávez government has maintained an ambiguous discourse and policy with respect to crime and violence. One could say that it has maintained two policies. When Chávez was elected, he represented a mixture of the images of a military and of a revolutionary and, although this seems illogical, for many people he represented their desire for change and their hope for order, the possibility of transforming the country while, at the same time, they hoped that he would ensure safety and take hard measures against the criminals. His image of a military favored the idea of the hard measures people had sought for such a long time, and his revolutionary behavior the possibility of change.

This duality was reflected in the policies of the government. On one hand, one observes a tolerant and even permissive policy towards crime, and the president himself said on several occasions that it was "understandable that people rob when they are in need". On the other hand however, there is a violent, repressive policy that led a vice-minister of public safety to declare proudly that, during that particular year, the police had eliminated more than two thousand "pre-delinquents" - a novel concept in criminal law, inexistent in the Venezuelan legislation.

But, there are policies that favor violence. One of these policies was the systematic disrepute the police was exposed to, that not only led to a wave of aggressions and verbal offenses, but also to measures for disarmament of the police force. In 2002, the television channel of the government transmitted systematically and repeatedly an advertisement for the Venezuelan film with the title Shoot to kill, the way television channels always do for preparing the audience for an opening. The scenes selected for promoting the film showed a police officer commanding an act of repression in a poor neighborhood. One saw the crime being committed by a policeman in a dark corner. After the noise of a shot, one could hear the long and desperate scream of the mother of the victim calling the policemen: Murderers! Before and after the advertisement, the channel transmitted propaganda against the political opposition of the government. This advertisement was broadcasted for a long time, but never announcing the date the film would be exhibited; months later a date was fixed, but neither that day nor 
in the following days the film was shown. The intention was apparently a different one.

This does not seem to be casual. At several opportunities, the President of the Republic engaged himself to contradict and old popular Venezuelan saying. For decades the Venezuelan children were taught, "violence is the weapon of those, who are wrong". The expression has been used for preventing young people in the schools from solving their conflicts by violence, but also to discourage adults to use violence, mainly during the passage of a rural society to urban life. It was surprising to observe how, in his speeches of several hours transmitted by all radio and television stations, the president several times said that this affirmation "is not true", suggesting that violence can be used and trying to change an idea he knew to be deeply rooted in the population.

Thus, one cannot be surprised that, in 1999, the number of homicides reached 5,974, increased to 9,244 in 2002, and came to exceed the number of 13 thousand victims in 2003. In other words, homicides tripled in six years of the so-called "beautiful revolution".

\section{The silence of the dead: 2004-2005}

The attentive reader will ask himself: and why the author does not refer to the homicide rates of the years 2004 or 2005? The answer is simple and sad: the official data of those years were not made available by the authorities. For the first time in the recent history, the homicide rates are not available to the public opinion, neither to the press nor to researchers. We sim- ply do not know what happened in the field of homicides in these years. Perhaps there is some public servant who thinks that homicides will stop if they are not published in the press and not investigated by researchers. Everyone must build his own judgment to this respect. To us personally this measure seems to confirm the worst, that is, there must have been a very important increase, otherwise why to hide the data?

The disappearance of homicide statistics takes the victimization to an even higher level, it wants to submit the victims to an even greater silence, it wants to make them more than anonymous: they already lost their life and their names, now they are not even allowed to be numbers. Nevertheless, we have some nonofficial data for the year 2004, obtained from persons we interviewed among others on victimization, in the course of a survey we carried out 24 .

Table 2 shows the results of the survey. One fourth of the population with more than 18 years of age declared having been victim of a robbery or some other act of violence (kidnapping, extortion, threats) in the twelve months previous to the survey, and 3\% declared that some relative had been assassinated. The number is quite high, but two details call for attention: on one hand, almost all homicides are reported and this is because murders are a public issue, not needing to be denounced for the police coming to action; on the other hand, the survey shows that only a third of non-fatal violence is reported to the authorities, demonstrating the lack of trust in the police system and justice. A second aspect deserving attention is the composition of the group of offenders, because in both homicides as robberies the

\begin{tabular}{|c|c|c|}
\hline \multicolumn{3}{|c|}{$\begin{array}{l}\text { Table } 2 \\
\text { Venezuela 2004. Victimization, identity of the offender and registry of ocurrence } \\
\text { (National sample, no. 1202). }\end{array}$} \\
\hline & $\begin{array}{c}\text { Some close relative } \\
\text { was assassinated in } \\
\text { the last } 12 \text { months? } \\
\%\end{array}$ & $\begin{array}{c}\text { Where you victim of } \\
\text { robbery or violence in } \\
\text { the last } 12 \text { months? } \\
\%\end{array}$ \\
\hline Victimization (\% positive answer) & 3.0 & 24.6 \\
\hline \multicolumn{3}{|l|}{ Who was the murderer or the offender? } \\
\hline A friend & 19.4 & 22.8 \\
\hline A relative & 5.6 & 2.0 \\
\hline A strange person & 55.6 & 72.8 \\
\hline Police or National Guard & 16.7 & 1.7 \\
\hline Did you inform the authorities (\% positive answer) & 91.7 & 35.0 \\
\hline
\end{tabular}

Source: LACSO. Survey on violence and criminal justice; 2004. 
fifth part of them were acquainted with the victims, showing the nearness of violence in an important part of cases. On the other hand, a fact that stands out is the high percentage of cases in which the homicide had been committed by police authorities or by the National Guard (a branch of the Armed Forces in charge of public safety), but the data of this survey do not allow to conclude if these facts occurred in fulfillment of their duty or in the course of legal actions. Anyway, it emphasizes the idea of an important increase in police violence.

\section{Where is Venezuela going?}

What is going to happen? What are the risks now? It seems that all scenarios are pointing to more violence in Venezuela.

The Chávez government represents one more step in the exacerbation of the rentist oil model, the same that came to languish since the 80 s and that suddenly received new breath with the remarkable increase of the petroleum prices in 2003. The statist and distributionist model won new force. The first - statism - was favored by the personality and the authoritarian ambitions of the president; and the second - distributionism - by the abundant flow of revenue received by the central government. The model is not new, it is the same one that brought Venezuela into more poverty and more violence.

Perhaps the defenders of $\mathrm{H}$. Chávez can claim some real changes. It is true that the elite in power before was deposed and replaced by a new one, which however did not show to be better. There was a change of actors, of names, but not of procedures. Government institutions instead of improving have gotten worse. For example, an important institutional procedure in a transparent governmental administration in almost all countries are the invitations to bid for companies and people who offer products or services to the State; in Venezuela there was a law that regulated and established the norms for competition between companies for public contracts. Presently, the invitations to bid were eliminated and the Minister or officer in charge decides according to his free will to whom the contracts will be granted. It is no surprise that corruption increased remarkably.

One may also recognize that the resources directly offered to the poor part of the society increased, but this does not imply in any substantial change because the model continues the same. The populist mechanisms already existed several decades before, to a smaller extent because there were less resources, but it is the same distributionism of the oil rent that we had in the past, only under an authoritarian military regime, hoisting different symbols, offering different sums, and using a different language.

With the populist strategy of giving money presents inside and outside the country the Chávez government could stabilize itself. This was due to the fact that, during the electoral campaign, the oil price was eight dollars the barrel and in the beginning of 2006 it surpassed 50 dollars, which means a budget six times higher than in the first year of his government and the highest in the history of Venezuela.

But the true consolidation as a hegemonic regime can only take place through more repression and violence against a society and some poor sectors, who claim their expectations enhanced by the continuous presidential promises, and unsatisfied with the precarious governmental administration. How much violence will be necessary to contain the political opposition and the social protest is difficult to anticipate. But it is very surprising that the new law of the Venezuelan Armed Forces foresees a branch of armed of reserves, in charge of internal safety, directly subordinated to the President of the Republic and not to the Minister of Defense.

Another aspect of violence has to do with the possibility of an open warlike confrontation with other countries, in special the announced war with the United States of America. The Venezuelan military doctrine was modified so as to include the USA as the main enemy, and establishes plans for a war called "asymmetric" or of the "fourth generation" for which purpose, according to the announcement of the President made in January 2006, it is foreseen to arm a million civilians with Ak47 guns. Probably all this is only empty talk, making part of a strategy of political distraction, but actually these messages are fomenting violence because they are breaking the social pact that contains it.

Another political scenario suggesting violence is a destabilization of the regime, loosing support and control, what could result in a change of power, be it through elections or through a military action. A transition by means of elections, although not impossible, does not 
seem easy under the political circumstances in Venezuela. A change resulting from a military action is not desirable but also not impossible in case the electoral ways are closed and discontent and political segregation increase. Both scenarios, however, make us predict more political violence because by what other means than a military revolt a government that resists to elections can be convinced to hand over the power?

In a context of political violence like the one we have described, criminal violence, the violence committed by bands and by the police, will tend to increase considerably because the violent individuals will find space for easy action and that is what has happened in the last years. This is what happened after the revolt of February 1989, when the first increase of homicide rates occurred, what happened after the attempts of a coup d'état in 1992, and this is also the explanation for the great increase in violence in Venezuela after 1999. The links between violence and public health are multiple and the explication of violent behaviors involves many other variables 25 , but here we wanted to emphasize two macrosocial aspects, the fluctuations of the oil rent and the political crisis, for considering them two fundamental components for understanding the dramatic increase of homicides in the Venezuelan society.

\section{References}

1. Irazabal C. Venezuela, esclava y feudal. Caracas: Editorial Ateneo; 1980.

2. Malave Mata H. Petróleo y desarrollo económico de Venezuela. Caracas: Ediciones Pensamiento Vivo; 1962.

3. Carrillo Batalla TE. La dinámica del desarrollo económico venezolano. Rev Latinoam Econ 1965; 17:45-68.

4. Araujo O. Situación industrial de Venezuela. Caracas: Ediciones de la Biblioteca de la Universidad Central de Venezuela; 1969.

5. Gabaldón A. Una política sanitaria. Caracas: Ministerio de Sanidad y Asistencia Social; 1965.

6. Martz JD, Myers DJ. Venezuelan democracy: perfomance and prospects. In: Martz JD, Myers DJ, editors. Venezuela: the democratic experience. New York: Praeger Publishers; 1986. p. 437-67.

7. Briceño-León R. Los efectos perversos del petróleo. Caracas: Fondo Editorial Acta Científica Venezolana, Consorcio de Ediciones Capriles; 1991.

8. Briceño-León R. Petroleum and democracy in Venezuela. Soc Forces 2005; 83(1):1-30.

9. Baptista A. El estado y el capitalismo rentístico. Caracas: Academia Nacional de la Historia; 2005.

10. Ricardo D. Des principes d'économie politique et de l'impôt. Paris: Flammarion; 1977. [1ier édition 1821].

11. Marx K. 1968. El capital. México: Fondo de Cultura Económica; 1968. [1a edición 1867].

12. Baptista A. Teoría económica del capitalismo rentístico. Caracas: Ediciones Iesa; 1997.

13. Furtado C. El desarrollo reciente de la economía venezolana. In: Valecillos H, Bello O, compiladores. La economia contemporánea de Venezuela. Caracas: Banco Central de Venezuela; 1990. p. 165-206.

14. Cordova A. La estructura económica tradicional y el impacto petrolero en Venezuela. Revista Economía y Ciencias Sociales 1963. 5(1):7-28.

15. Briceño-León R. Venezuela: clases sociales e individuos. Caracas: Fondo Editorial Acta Científica Venezolana, Consorcio de Ediciones Capriles; 1992.

16. Ugalde L. La violencia en Venezuela. Caracas: Monteavila Universidad Católica Andres Bello; 1990.

17. Venzuela. Banco Central. Informe económico. Caracas: BCV; 1975,1985, 2004.
18. Baptista A. El relevo del capitalismo rentístico: hacia un nuevo balance del poder. Caracas: Fundación Polar; 2004.

19. Marquez G.Venezuela: poverty and social policies in the 1980s. In: Lustig N, editor. Coping with austerity: poverty and inequality in Latin America.Washington, DC: The Brookings Institution; 1995.

20. Berglund S. La población extranjera en Venezuela de Castro a Chávez. In: Las inmigraciones a Venezuela en el siglo XX. Caracas: Fundación Francisco Herrea Luque; 2005. p. 35-50

21. Briceño-León R. Contabilidad de la muerte. In: El Nacional, organizador. Cuando la muerte tomó la Calle. Caracas: Editorial Ateneo; 1990.

22. Sanjuan A M. La criminalidad en Caracas: percepciones y realidades. Rev Venezolana Econ Ciencias Soc 1997; 3(2-3):215-54.

23. Molina JE. Partidos y sistema de partidos en la evolución política venezolana: la desinstitucionalización y sus consecuencias. In: Molina JE, Álvarez AE, coordinadores. Los partidos políticos venezolanos en el siglo XXI. Caracas: Vadell Editores; 2004. p. 9-56.

24. Laboratorio de Ciencias Sociales, Instituto de Ciencias Penales de la Universidad Central de Venezuela, Instituto de Criminología "Lolita Aniyar de Castro" de la Universidad del Zulia. Encuesta Nacional de Violencia Urbana y Sistema de Justicia Penal. Caracas; 2004.

25. Briceño-León R. Urban violence and public health in Latin America: a sociological explanatory model. Cad Saúde Publica 2005; 21(6):1629-64.

26. Venezuela. Ministerio de Interior y Justicia. Archivos de Dirección de Prevención del Delito. Caracas: MIJ; 2004.

27. Venezuela. Ministerio de Planificación y Desarrollo. Instituto Nacional de Estadística. Proyecciones de de población. Caracas:MPD; 2004.

Article presesented in 28/03/2006

Approved in 31/03/2006

Final version presented in 14/04/2006 